Available Online : http://journals.researchsynergypress.com/index.php/jefltr/index

Journal of English as A Foreign Language Teaching and Research (JEFLTR)

ISSN 2776-4524 (Online) | 2776-4184 (Print)

Volume 1 Number 1 (2021): 61-70

\title{
Information Communication Technology in EFL Classroom
}

\author{
1Khalid Beni Akhy, ${ }^{2}$ Weningtyas Parama Iswari \\ ${ }^{1}$ Amria High School in Beni Mellal. Morocco \\ ${ }^{2}$ Mulawarman University, Indonesia
}

\begin{abstract}
Information Communication Technology (ICT) has penetrated into the teaching of English as a foreign language (EFL) around the world, not to mention in Morocco. However, due to some obstacles faced in its implementation, its effectiveness needs to be improved. This paper is intended to explore the potentials of ICT to be used in EFL classes in Morocco and how to prepare teachers to be ready in incorporating the ICT in their language teaching. The potentials cover, among others, what multimedia resources are available, how to make use of them and how ICT becomes the tools to develop student's English language skills. As the teachers' role is very significant, they should get professional development training in ICT for education.
\end{abstract}

Keywords: ICT, EFL, Multimedia, Language skills

This is an open access article under the CC-BY-NC license.

\section{INTRODUCTION}

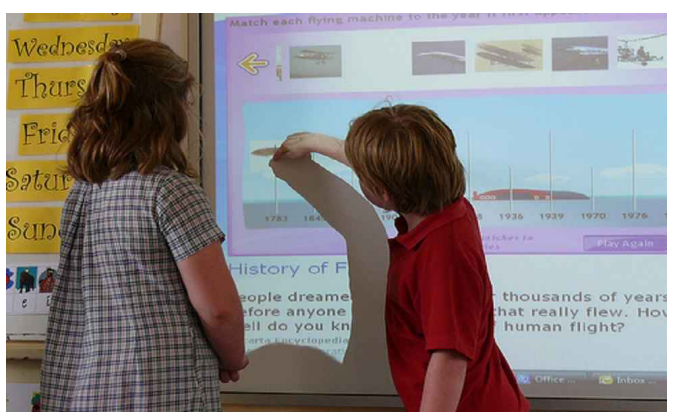

Information communication technology (ICT) has become an integral part of people's lives recently. Teaching English as a foreign language in Morocco has begun to take advantage of the potential of technology, as is the case in most parts of the world. However, the implementation and effectiveness of ICT in language classrooms has not reached its full potential as yet in Morocco. Research is still needed to investigate such areas as teachers' and students' perspectives on the use of ICT, the ways these are implemented, and the challenges involved in implementing them. Using ICT in class in the Moroccan context is challenged by many obstacles like the availability of these technologies in adequate quantities, access to the Internet, teacher training in using ICT, teachers' and students' views on ICT, the consistency and efficiency of ICT use by teachers, and finally, the provision for ICT implementation by syllabus and textbook designers.

This article attempts to answer several questions, including the following: What is the potential if ICT? How do teachers of English as a foreign language integrate ICT in their lessons? What are the different functions that ICT have in our language lessons? How are teachers using ICT? What are the challenges involved when using ICT in language classrooms? And what training is available for teachers?

\section{LITERATURE REVIEW}

In recent years, there has been a significant advancement in information and communication technology around the world. Most teachers in the European Union use ICT to plan lessons, and several countries have invested in ICT in terms of equipment, accessibility, professional development, and digital learning materials. The popularity of ICT tends to be the same in other Corresponding author : Khalid Beni Akhy: khalidbeniakhy@gmail.com DOI: $10.31098 /$ jefltr.v1i1.485 
Journal of English as A Foreign Language Teaching and Research (JEFLTR)

Vol. 1(1), 61-70

Information Communication Technology in EFL Classroom

Khalid Beni Akhy, Weningtyas Parama Iswari

parts of the world. The Office of Educational Technology in the United States has developed a technology strategy to enhance education through the use of ICT. In Africa, however, the use of technology in secondary English language education is increasing. As a result, the horizons of technology and education are connected.

Multimedia displays can stimulate both hemispheres of the brain and improve memory more than a single medium, and digital multimedia systems allow access to learning materials more effective than print media. Playbacks and slowing down the pace are both possible with digital technologies, making learning even more accessible to the learner (Hanson-Smith, 1999). Nutta (1998) compared students who spent the same amount of time studying verb tenses in English in a normal class and receiving instruction from the teacher to students who used a multimedia computer program and found that the students using the computer program performed as well as or marginally better than their peers who used conventional methods.

Using video and the Internet can enhance access to authentic resources in the second or foreign language (Bacon \& Finnemann, 1990). The performance of learners who practised listening comprehension and oral development with videos was found to be superior to that of the standard community who used textbooks. ICT is successful, according to Poór (2006), in the sense that various multimedia programs allow self-correction and self-evaluation. They can be used as a source for diagnostic and achievement tests. Some multimedia incorporates the practice of pronunciation and elementary units for interaction in a comparative way that parallels language lab applications to some degree, using built-in microphones and web cameras on the screen. However, valuable learning materials must also provide enough challenging materials (Krashen, 1985). Authentic materials, especially for beginning and intermediate learners, provide material that is often beyond their language level and can become unintelligible without the teacher's help.

\section{ICT and Communication}

ICT has been used in a variety of ways to provide opportunities for language learners to communicate in the target language, and it has been used in a variety of ways to build opportunities for language learners to communicate in the target language. Efforts in this field can be divided into two categories: user interaction and computer interaction with remote audiences. Interactions may take place in written, spoken, or both languages, with a computer program generating utterances orally or in writing that enable the learner to respond by selecting an answer with a mouse click or offering simple writing responses (Hanson-Smith, 1999). Students could use speech recognition technology to conduct oral interviews with simulated native-speaking characters in some programs. The participants' reading, speaking, and listening skills improved dramatically after engaging with these fictional characters for at least 8 hours a day for four days.

Since the 1980s, language learners have used computer-mediated communication (CMC) with remote audiences to establish authentic communication opportunities (Beauvois, 1997). Language learners have found that using CMC technology like e-mail, bulletin boards, and chatrooms has a range of advantages. More fair and better participation is improved by CMC, resulting in more performance in the target language (Beauvois, 1997). Although CMC communication is most often encoded in text, it has been discovered that it can also promote oral communication. For example, according to Beauvois (1997), second-year French students who conducted their discussions online improved their oral proficiency more than those who discussed the texts orally in a traditional classroom environment.

\section{ICT provides immersion}


Journal of English as A Foreign Language Teaching and Research (JEFLTR)

Vol. $1(1), 61-70$

Information Communication Technology in EFL Classroom

Khalid Beni Akhy, Weningtyas Parama Iswari

Kickmeier-Rust et al. (2007) propose the use of immersive interactive games as tools for next-generation learning. Immersive learning uses 3D specialized computer applications to model real-world scenarios. Immersive learning systems, such as immersive simulations, are commonly used in high-stakes learning environments like space training, medical education, and piloting, as well as car driving. Nonetheless, since these simulations are very costly and time-consuming to create, their use in education has been minimal (Herrington et al., 2007). Other forms of ICT are available and provide exposure to foreign language, which is a rudimentary form of immersion in the foreign language. Immersion corresponds to Krashen's concept of "comprehensible input," or a language understood without the learner comprehending all of the message's linguistic types. Nowadays, any learner can find enough comprehensible feedback for a kind of virtual immersion thanks to the availability of English-language content on the Internet.

Immersion allows for the production of comprehensible output or the co-construction of sense. Immersion and Machine Aided Language Learning (CALL) pedagogy boost at least three dimensions of production theory. For starters, learners have the ability to prepare ahead of time before speaking or writing. Second, the cognitive viewpoint stresses the importance of opportunities to correct linguistic performance, which can be prompted by other people's input or by self-evaluation. Third, the socio-cultural viewpoint indicates the concept of scaffolding, which relates to the value of learners using the interlocutor's assistance to allow for output beyond what the learner might achieve on their own, also known as the zone of proximal growth.

\section{ICT increase engagement}

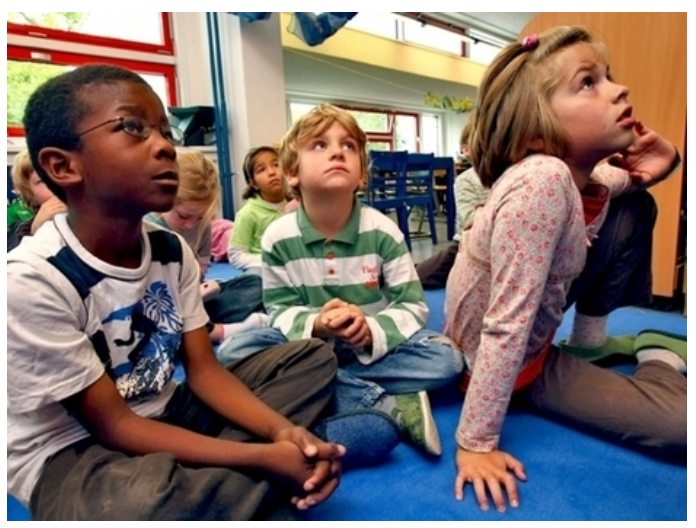

The encouragement of students is the driving force behind the use of ICT in the classroom. Most of the academic research on YouTube focuses on how its multimodality can help students become more motivated. YouTube videos can help students learn in a variety of ways by covering at least four different types of bits of intelligence, including verbal/linguistic, visual/spatial, musical/rhythmic, and emotional bits of intelligence. Students' enthusiasm and comprehension are increased and deepened by watching videos, which allows brain reactions in both hemispheres.

Several experimental studies have been conducted to investigate the effect of YouTube videos on student motivation, with the advantages of catching students' attention by offering additional visual reinforcement being highlighted. Desmet (2009), who researched students' learning of Shakespeare literature with YouTube, found that it had a positive impact. Trained English Language Arts teachers can use YouTube videos to help students interpret complicated texts in a creative way. Furthermore, students gain a greater understanding of not only the material but also the text's satire and irony, which English literature teachers often find difficult to convey (Desmet, 2009). YouTube can be used in a variety of ways to improve language skills, genre understanding, and vocabulary learning in context. Students can learn the real-life language on YouTube as well since the site's authentic texts emphasize cultural competence and realistic considerations.

\section{ICT and active learning}


Journal of English as A Foreign Language Teaching and Research (JEFLTR)

Vol. 1(1), 61-70

Information Communication Technology in EFL Classroom

Khalid Beni Akhy, Weningtyas Parama Iswari

E-learning offers invaluable opportunities for learner autonomy as described in learnercentred approaches in which students are actively engaged in the process of constructing their own knowledge, rather than being spoon-fed through the practice of rote memorization. Rita-Marie Conrad, in building on the foundational learner-centred and constructivist conclusions of authors like Dewey, Piaget, and Vygotsky, recommends us to remember that in online courses, learners must be "active knowledge-generators" and must "assume responsibility for constructing and managing their own learning experience" (2004). Online learning environments that foster active learning in real-time increases learners' active involvement and makes the presence of a facilitator merely guide an experience that the learner clearly manages. This shows how ambient learning can enhance active learning by developing better problem-solving skills and equipping them with skills they can put to use immediately outside the live class context.

\section{Prompt feedback}

In real-time learning environments, learners know how and when they get instructor feedback, understand it and begin to take it into consideration, or they might seek clarification and receive instant feedback, thus creating an experience that constantly builds upon itself. In online learning environments, where students lack many of the conventional non-verbal techniques required in face-to-face communication, prompt feedback is critical. Instant feedback tools provide students with a variety of ways to gain immediate feedback, both during planned activities and in real-time interactions with their teachers. Computers are able to provide synchronous and individualized feedback. While the behaviourist approach essentially evaluates the learner's success and provides simple guidance in a correct-or-incorrect manner, more modern applications such as computer-based grammar and spell checkers are far more contextualized and pedagogically sound (Salaberry, 2001).

Automatic speech recognition technology can provide feedback to learners' performance. Feedback and modelling are often given by a teacher in typical instructional environments, who may or may not be effective at determining student pronunciation by making students repeat the pronunciation or demonstrating how the sound should be expressed. With the advent of speech recognition technologies, students may be able to receive input more efficiently (Eskenazi, 1999).

\section{Integrating ICT for the four skills}

\section{Speech and Pronunciation}

Songs, rhymes, and popular stories with repetitive language forms have long been used as effective classroom strategies. Via recorded songs, talking electronic books, podcasts, and video clips, the Internet can be a rich source of authentic oral models that assist learners in pronunciation as well as the learning and reinforcement of new vocabulary. These resources can also assist teachers who are unsure of their own language abilities. Technology also helps children to record themselves for later retrieval to assist in the detection of grammatical errors and pronunciation defects, fostering self-sufficiency.

Young children can use video cameras to monitor their vocal organs in order to improve phonetic accuracy; the recordings can then be compared to standard models available on the Internet. Songs and poetry, for example, can be downloaded from the Internet and performed as a class using an interactive whiteboard before a live presentation that can be recorded and visualized by other students. Uncommunicative speakers have also been encouraged to use oral language more freely in the classroom using audio recorders; a child makes a recording in isolation and plays it back in the classroom, confirming their speech to their peers (Howard \& Pim, 2007). 
Journal of English as A Foreign Language Teaching and Research (JEFLTR)

Vol. $1(1), 61-70$

Information Communication Technology in EFL Classroom

Khalid Beni Akhy, Weningtyas Parama Iswari

Teachers are struggling to provide pronunciation instruction in their classrooms using the communicative approach to language learning, which stresses the authentic use of language (Hincks, 2003). On the one hand, teachers may be uncertain if specific drilling will enhance pronunciation, or they may believe they lack the knowledge skills to provide sufficient input (Hincks, 2003). Because of time constraints and a desire not to disrupt their students' contact flow, they rarely address pronunciation in their classrooms.

Explicit pronunciation instruction and input, at both the individual sound and supraprosodic levels, which include aspects of stress, rhythm, and intonation, have been shown to support and be appreciated by language learners in studies (Hardison, 2004). Computer-Assisted Pronunciation Training (CAPT), especially that based on Automatic Speech Recognition (ASR) technology, often includes visual sound screen representations and can provide learners with personalized feedback on their pronunciation errors (Godwin-Jones, 2009). They can easily be introduced in the classroom, or they can be registered and posted for teachers to respond to later by providing targeted feedback (Ducate \& Lomicka, 2009). Advantages of this ICT include individualized attention through feedback; learners may proceed at their own pace; repeat exercises as many times as required; and get exposed to a variety of native-speaking models (Godwin-Jones, 2009).

\section{Listening}

Listening comprehension and vocabulary learning will also benefit from the use of technology. With each repetition, narrow listening, or listening to an oral text repeatedly, will increase understanding and lead to better use of cognitive strategies (Dupuy, 1999). When language learners communicate with oral texts that contain captions, they can acquire new vocabulary, enhance their listening comprehension, and increase their motivation (Baltova, 1999). Available tools can be self-directed, giving students the option to replay the file as many times as they need (Gruba, 2010). Optional captions, subtitles, and transcriptions may be added to audio and video files. Students can increase their understanding by slowing down the pace of an audio file (Zhao, 1999).

\section{Reading}

In teacher-determined classes, the teacher pre-selects authentic resources in online environments but also includes learning-guided practice exercises and nonlinear elements like hyperlinks to other websites. Learners choose the subjects for learner-determined lessons and then coordinate their own quest for online reading materials. These could be better suited to intermediate and advanced students.

Vocabulary retention can be improved with computer-assisted tools like lexical training programs and multimedia annotations inside texts that provide access to electronic dictionaries and internal glossaries while reading, particularly for intermediate-level second language learners (Chun, 2011). According to some research, having access to online dictionaries and digital annotations inside texts such as notes, definitions, and remarks improves and tracks reading comprehension (Chun, 2011).

\section{Writing}

Some online apps assist with simple style and grammar correction and deal with writing skills. Language learning software programs such as Tell Me More, Rosetta Stone, and Slick Write provide editing tips at the word and sentence level for language learners. Some programs enable 
Journal of English as A Foreign Language Teaching and Research (JEFLTR)

Vol. 1(1), 61-70

Information Communication Technology in EFL Classroom

Khalid Beni Akhy, Weningtyas Parama Iswari

students to respond to written texts uploaded by the teacher through activities such as gap fills, text predicting, word unscrambling, and sentence order, which can serve as pre-writing warm-up exercises (Camsoft, 2011). Other apps use Computer-Mediated Communication (CMC), such as email and messaging Web 2.0 (social media) tools that enable many users to edit a document that is saved and posted online (Godwin Jones, 2008). Some authentic text collections can be used in the classroom as templates for exposing students to various types of writing in the target language (Cotos, 2011).

Programs that are capable of correcting common grammar and spelling errors, such as the spell and grammar checking software for a variety of languages found in Microsoft Word, have been used with language learners with positive results (Rimrott \& Heift, 2008). Some higher-level writing software that can provide feedback at the sentence and discourse level has been developed for writing in English may benefit EFL learners (Beauvois, M. (1997).

\section{Teacher Training and Continuing Professional Development in ICT}

According to research, teacher training in how to use ICT skills is critical in integrating ICT incorporation in English teaching and learning, and the standard of teacher training in how to use computers to help to learn is a critical factor in assessing the degree to which technology has an effect on achievement (Samuel and Zitun, 2007). Teachers also develop their own personal learning networks (Couros, 2008) and interact with other teachers all over the world to share what they know and assist others in learning through Personal learning networks (PLNs), resulting in content, information, and process. Perkins describes continuing professional development (CPD) as "very personal" and "an outstanding barometer of a teacher's level of enthusiasm" for their chosen profession (Perkins, 2002).

Teachers who interact with colleagues online and learn how to use technology are often active in their colleagues' ICT training. Being a member of a vast online network of ICT-using language teachers ensures you get daily updates on classroom technology from practising teachers. Not all secondary teachers have access to technology, but the so-called "digital divide" is as much a literacy problem as it is an economic one (Pegrum, 2009: 4), with the teacher in question addressing the lack of technology by bringing their own laptop computer to class and working with their students to link their language learning to the real world outside the classroom.

\section{DISCUSSION}

In fact, while ICT-mediated exposure to the target language can improve students' ability to understand spoken language, in particular, immersion is restricted in terms of grammatical competence and, in particular, the ability to produce grammatical language. L2 comprehension, preparation, and production; motivation; and attention to, and perception of, L2 sense and form are often emphasized from a cognitive standpoint. While communicative competence encompasses a wide range of communication and interaction, from collaborative exchange to instructional involvement, it also includes mediation through meaning negotiation.

While ICT promotes authentic language learning and serves as a motivator, concerns about privacy and copyright remain. Other forms of content may be difficult to procure since their use is forbidden in some schools. Other concerns include content that is no longer available, as well as commercials that are unacceptable for students to see. Images, on the other hand, can be downloaded and modified before being displayed in class. 
Journal of English as A Foreign Language Teaching and Research (JEFLTR)

Vol. $1(1), 61-70$

Information Communication Technology in EFL Classroom

Khalid Beni Akhy, Weningtyas Parama Iswari

Some studies have documented a variety of issues, including a lack of suitable videos and a failure to fully utilize the videos, stressing the importance of choosing appropriate content with strong educational value. When choosing YouTube videos, teachers are required to be stringent in terms of content credibility, accuracy, and reasonableness. Before using their instructional materials, teachers can conduct student surveys to learn more about their interests (Berk, 2009). In reality, choosing a song for a class is often done without taking into account the preferences of students or taking into account their age, language proficiency, or syllabus material.

Although it is important to think about the YouTube videos to play in class and how to use them, Ow and Lew (2014) found that YouTube was ineffective in assisting learners who passively watched the videos. Hamilton (2010) also emphasizes the importance of using videos in sequential order. Interaction with the teacher and peers is also very significant. Jones and Kristen have made some suggestions for using YouTube to teach English (2011). YouTube can be used as an attentiongetting tool in the classroom or as a teacher resource where videos can be used as a model for classroom events or discussions. Videos are just a part of the lesson in this situation. Some videos, however, do not lend themselves to classroom use. They can also be used as launching pads for classroom events or as inspiration for teachers' lesson plans.

More than just assisting the teacher in delivering teacher-centred lessons should be the aim of videos. Students may use the tool's engagement to learn the language in a social setting by creating their own video, leaving feedback, sharing it on their websites, and so on (Hamilton 2010) Pronunciation-assist technologies have not been effective in decoding spontaneous, naturally accented foreign expression (e.g., Kamper et al., 2012). Exercises are often restricted by the requirement that they use pre-defined vocabulary. Furthermore, language learners' expression is not always easily recognized by software programs, resulting in incorrect feedback (Engwall \& Bäälter, 2007). The use of captions, subtitles, and slower speech in listening videos does not often prepare students for realistic listening experiences outside of the classroom (Vandergrift, 2004). However, captions, subtitles, and slowed-down speech will not make content available to the learner that is completely beyond his or her skill level (Guillory,1998).

Furthermore, standardized online high-stakes listening assessments, such as the IELTS, do not accurately represent real-life listening situations. Since test subjects are only able to hear an audio file once at normal speed and without any visual background, this may not be a true reflection of real-world listening ability.

In terms of reading, students would need data processing skills to deal with complex and nonlinear information structures such as hyperlinks, glossaries, and so on. This may indicate that students are having difficulty comprehending what they see on a computer screen.

As to writing, software designed to support and provide feedback to beginning writers, like SlickWrite, doesn't make for Loops to External resources for writing, publishing, dictionaries, websites, pop-ups. Further, it doesn't help the user to personalize his learning experience by changing the settings and tools, for example. Teachers are occasionally left to fend for themselves. They are shifting for themselves or learning how to use readily accessible, free online resources across social networks and online communities of practice.

All things considered, If the systems and processes suffer from structural deficiencies, then using ICT will not help. The implementation of ICT requires a preliminary stage to analyze and cleanse the system before introducing ICT. We should do the right things instead of doing things right. Exposure to ICT provides learners with an edge in a technologically invaded workplace, helps 
Journal of English as A Foreign Language Teaching and Research (JEFLTR)

Vol. 1(1), 61-70

Information Communication Technology in EFL Classroom

Khalid Beni Akhy, Weningtyas Parama Iswari

them with research projects, enhances learner autonomy, enriches teacher development opportunities, and actually makes the processing of information a powerful asset with the support of ICT.

However, ICT cannot make useless outcomes useful. ICT is cost and time effective, but proper use is often debatable. Appropriate system and methodology selection are therefore important because whatever you get from the computer is what you've put into it; and The implementation of ICT is added value only as long as it reduces the processing time of activities and makes the system less error-prone but the main concern is with the activities, processes and ultimately their sequence to achieve the final objective or goal.

\section{CONCLUSION}

ICT and education are increasingly connected, including in the field of language learning and teaching. ICT can be a tool to increase learners' interaction which becomes the opportunities to use English as the target language. It also makes immersive learning possible and provides comprehensible input. ICT has the potential to be multimodality resources, such as videos, that trigger learner engagement, active learning and immediate feedback. Students' language skills (i.e. listening, speaking, reading and writing) can be developed with the help of technology through a wide range of online programs and applications. As for the teachers, professional development pieces of training, such as computer pieces of training and learning networks, need to be provided

\section{REFERENCES}

Bacon, S., \& Finnemann, M. (1990). A study of the attitudes, motives, and strategies of university foreign language students and their disposition to authentic oral and written input. The Modern Language Journal, 74, 459-473.

Balanskat, A, Blamire, R. \& Kefala, S. (2006). The ICT Impact Report: A review of studies of ICT impact on schools in Europe. European Schoolnet. Available online at https://oei.org.ar/ibertic/evaluacion/sites/default/files/biblioteca/31 theict impact repo rt in europe.pdf

Baltova, I. (1999). Multisensory language teaching in a multidimensional curriculum: The use of authentic bimodal video in core French. The Canadian Modern Language Review/La Revue Canadienne des Langues Vivant, 56(1), 31-48.

Beauvois, M. H. (1997). Computer-mediated communication(CMC): Technology for improving speaking and writing. In R. M. Terry (Ed.), technology-enhanced language learning (pp. 165184). Lincolnwood, Illinois: The National Textbook Company.

Berk, R. A. (2009). Multimedia Teaching with Video Clips: TV, Movies, YouTube, and MTV U in the College Classroom. International Journal of Technology in Teaching and Learning, 5(1), 1 -21.

Chun, D. M. (1998). Signal analysis software for teaching discourse intonation. Language Learning \& Technology, 2(1), 74-93. Retrieved from: https://scholarspace.manoa.hawaii.edu/bitstream/10125/25033/1/02_01_article4.pdf

Cotos, E. (2011). Potential of automatic writing evaluation feedback. CALICO Journal, 28, 420-459. 
Journal of English as A Foreign Language Teaching and Research (JEFLTR)

Vol. 1 (1), 61-70

Information Communication Technology in EFL Classroom

Khalid Beni Akhy, Weningtyas Parama Iswari

Couros, A. (2008). What is a PLN? Or, PLE vs PLN? Open Thinking. Available online at https://educationaltechnology.ca/1156

Delcloque, P. (2021). History of CALL. Available online at www.history-of-call.org/

Desmet, C. (2009). Teaching Shakespeare with YouTube. The English Journal, 99(1), 65-70.

Ducate, L. \& Lomicka, L. (2009). Podcasting: An effective tool for honing language students' pronunciation? Language Learning \& Technology, 13(3), 66-86.

Dupuy, B. (1999). Narrow listening: An alternative way to develop listening comprehension in the foreign language classroom. The system, 27, 351-361.

Godwin-Jones, R. (2009). Emerging technologies: Speech tools and technologies. Language Learning \& Technology, 13(3), 4-11. Retrieved from: http://citeseerx.ist.psu.edu/viewdoc/download?doi=10.1.1.580.9180\&rep=rep1\&type=pdf

Guillory, H.G. (1998). The effects of keyword captions to authentic French video on learner comprehension. CALICO Journal, 15(1-3), 89-108.

Hamilton, R. (2010). YouTube for two: Online video resources in a student-centred, task-based ESL/EFL Environment. Contemporary Issues in Education Research, 3(8), 27-32.

Hanson-Smith, E. (1999). Classroom practice: Using multimedia for input and interaction in CALL environments. In E Hanson-Smith (Ed.), CALL environments: research, practice, and critical issues (pp. 189-215). Alexandria, VA: TESOL.

Hardison, D. (2004). Generalization of computer-assisted prosody training: Quantitative and qualitative findings. Language Learning \& Technology, 8, 34-52. URI/DOI: 10125/25228

Hincks, R. Speech technologies for pronunciation feedback and evaluation. ReCALL, 15,3-20. (, 2003).

Howard, L \& Pim, C. (2007). Animating the curriculum: Developing and preserving traditional stories through online collaboration and digital publishing. NAACE Computer Education, Issue 115.

Krashen, S. (1982). Principles and practice in second language acquisition. Oxford: Pergamon.

Krashen, S. (1985). The input hypothesis: Issues and implications. London, New York: Longman.

Labrie, G. (2000). A French vocabulary tutor for the web. CALICO Journal, 17 (3), 475-499.

Nutta, J. (1998). Is computer-based grammar instruction as effective as teacher-directed grammar instruction for teaching L2 structures? CALICO Journal, 16(1), 49-62.

Office of Educational Technology. (, 2010). National educational technology plan. Office of Education, US Department of Education. Available online at https://tech.ed.gov/netp/

Ow, S. H. \& Lew, T.W. (2014). Interactivity in Learning Between Using an English Alphabet Learning Package and YouTube Alphabet Learning Videos. SDIWC Organization. 173-181.

Pegrum, M. (2009). From blogs to bombs. Crawley: UWA Publishing.

Pennington, M.C. (1996) The power of CALL. Houston: Athelstan.

Perkins, A. (2002). Continuing professional development: Sojourn or Odyssey. In Edge, J (ed): Continuing Professional Development: Some of our Perspectives. Whitstable, UK: IATEFL Publications.

Salaberry, M.R., (2001). The use of technology for second language learning and teaching: A retrospective. The Modern Language Journal 85/1: 39-56. 
Journal of English as A Foreign Language Teaching and Research (JEFLTR)

Vol. 1(1), 61-70

Information Communication Technology in EFL Classroom

Khalid Beni Akhy, Weningtyas Parama Iswari

Samuel, R.J. \& Zitun, A.B. (2007). Do teachers have adequate ICT resources and the right ICT skills in integrating ICT tools in the teaching and learning of English in Malaysian schools? The Electronic Journal on Information Systems in Developing Countries.

Sárosdy, J., Farczádi, T. B., Poór, Z. \& Vadnay, M. (2006). Applied linguistics for BA students in English. Bölcsész Konzorcium. Minden jog fenntartva Bölcsész Konzorcium. HEFOP-3.3.1-P.-2004-090134/1.0

Shrum, J. \& Glisan, E. W. (2009). The teacher's handbook: Contextualized language instruction 4th Edition. Boston: Heinle and Heinle.

Stanley, G. (2013) Integrating technology into secondary English language teaching. In Motteram, G.: Innovations in learning technologies for English language teaching. London: British Council Vygotsky, LS (1978). Mind in society: The development of a higher psychological process. Cambridge, MA: Harvard University Press.

Weyers, J. R. (1999). The effects of authentic video on communicative competence. The Modern Language Journal, 83 (3), 339-349.

Zhao, Y. (1997). The effects of the listener's control of speech rate on second language comprehension. Applied Linguistics, 18 (1), 49-68. 